Zaidan et al. / Basrah J. Agric. Sci., 32(2): 7-15

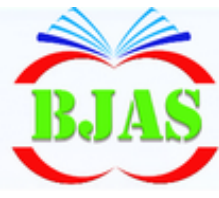

ISSN $1814-5868$
Available online at http://journal.bajas.edu.iq College of Agriculture, University of Basrah

DOi:10.21276/basjas

Basrah J. Agric. Sci., 32(2): 7-15, 2019
Basrah Journal

of Agricultural Sciences

E-ISSN: 2520-0860

\title{
Effect of Genotypes and Tillage Systems in some Growth Characteristic of Maize (Zea mays L.)
}

\author{
Safaa A. Zaidan' ${ }^{1}$ Kareem H. Mohsin ${ }^{2}$ \& Sadiq J. Muhsin ${ }^{3 *}$ \\ ${ }^{1}$ Agriculture Directorate of Basrah, Ministry of Agriculture, Iraq. \\ ${ }^{2}$ Department of Field Crops, College of Agriculture, University of Basrah, Iraq. \\ ${ }^{3}$ Department of Agricultural Machines and Equipment, College of Agriculture, University \\ of Basrah, Iraq. \\ *Corresponding author e-mail: sadigar75@gmail.com \\ Received 19 July 2019; Accepted 13 October 2019; Available online 30 October 2019
}

\begin{abstract}
A field experiment was conducted during autumn season 2018 in Al-Qurna Agriculture research station which is located in about $70 \mathrm{~km}$ away north of AL-Basrah Center at $47^{\circ} .45^{\prime}$ east longitude and $31^{\circ} 00^{\prime}$ north latitude. The aim is to Study the effect of three tillage systems (No tillage; T1, chisel plow a depth of $30 \mathrm{~cm}$ plowing $+10 \mathrm{~cm}$ disc harrows a depth of $10 \mathrm{~cm}$; T2, Moldboard plow a depth of plowing $30 \mathrm{~cm}+$ disc harrows a depth of $10 \mathrm{~cm}$; T3) on some growth characters of some maize genotypes (Zea mays L.). The genotypes were Fajer-1 (V1), Baghdad-3 (V2), Al-Maha (V3), Sara (V4). The design of the experiment was randomized complete block design (RCBD) in a split plot arrangement with three replications. The results showed that the tillage system T3 was superior as compared to other tillage systems in stem diameter, while as the treatment T2 was superior in number of days up to $50 \%$ tasseling and leaf area. The cultivar Maha (V3) was superior as compared to other cultivars in number of days up to $50 \%$ tasseling and leaf area. The interaction between corn genotypes and tillage system was significant on leaf area, that is the genotype V3 under the tillage system T2 gave the highest leaf area reached to $4847.893 \mathrm{~cm}^{2}$.
\end{abstract}

Key words: Maize genotypes. Tillage systems. Leaf area. Stem diameter

\section{Introduction}

Corn (Zea mays L.) is one of the most important food crops grown worldwide. It is the most widely grown cereal in a world. Based on the total area and production, maize is the 3rd most important cereal crop after wheat and rice in the world (Haddadi, 2016). It is widely used as cereals and other forms of food for human as bread and oil, and for feeding of farm animals, in addition to multiple industrial products (Abdullah \& Karim, 2019). Variability of genotypes is a key to crop improvement and essential success (Al-Obaidy et al., 2015). Corn is cultivated in most governorates of Iraq, but 


\section{Zaidan et al. / Basrah J. Agric. Sci., 32(2): 7-15}

the average yield is still lower than the average of developed agricultural countries, such as United States (1044 $\left.\mathrm{T} \mathrm{ha}^{-1}\right)$, Turkey $\left(10.75 \mathrm{~T} \mathrm{ha}^{-1}\right)$ and Canada $\left(9.72 \mathrm{~T} \mathrm{ha}^{-1}\right)$ (USDA, 2019). Corn cultivars were an important component. Khether (2017) in his study on corn genotypes reported that the maximum leaf area resulted from genotype $\mathrm{G}_{2} 5833 \mathrm{~cm}^{2}$ and minimum leaf area resulted from genotype $\mathrm{G}_{1}\left(4933 \mathrm{~cm}^{2}\right)$. Kökten \& Akçura (2017), in their study on corn during 2 years using twenty five genotypes concluded that, the average stem diameter of Dian genotype was at least $2.60 \%$ more than the stem diameter of safak genotype at $5 \%$ probability level. The cultivars differed significantly in their response to different tillage treatments (Khorami et al., 2018). Tillage is one of the most important processes in the field, it has an important role in improving the physical properties of the soil (Muhsin, 2017), in addition to create a suitable seedbed and helps to increase the root system growth which leads to increase the vegetative growth due to fracture of layers under soil surface (Al-Rubaie \& AlUbaidi, 2018). The use of mechanized processes is considered the main factor contributing to the total energy inputs in agricultural systems. Tillage represents half of the operations carried out annually in the field. Consequently, there is a potential to reduce energy inputs and production costs by zero tillage (Osunbitan et al., 2005; Ozturk et al., 2006). A number of researchers had found modern agricultural systems, including zero tillage which is characterized as an agricultural system that eliminates all tillage operations and prepares a seed bed by opening a line to place the seed in the soil. The agricultural systems in a number of countries were used this system of cultivation of crops without tillage because of its many benefits, notably reducing the effort and time required for tillage, reducing the use of machinery (Alrijabo, 2012). Shahzad et al. (2015) found during 2 years experiment using three tillage systems that, the maximum Stem diameter resulted from treatment of deep tillage $(13.6 \mathrm{~mm})$ and minimum Stem diameter resulted from minimum tillage $(12.3 \mathrm{~mm})$. The aim of current study was to determine the response of four corn genotypes to different tillage systems and their impact on the characteristics of growth.

\section{Materials \& Methods}

A field experiment was conducted during the autumn season 2018 in AlQurna Research Station of the Office of Agricultural Research which is located at 70 $\mathrm{km}$ to the Basra center at $47^{\circ} .45$ east longitude and $31^{\circ} .00$ north latitude. The aim of this study was to identify the response of four corn genotypes (Fajer-1, Baghdad-3, Al-Maha and Sara) that given the symbols $\mathrm{V}_{1}, \mathrm{~V}_{2}, \mathrm{~V}_{3}$ and $\mathrm{V}_{4}$ to three tillage Systems. No tillage $\left(T_{1}\right)$, chisel plow a depth of $30 \mathrm{~cm}$ plowing + disc harrows a depth of $10 \mathrm{~cm}$ $\left(\mathrm{T}_{2}\right)$, Moldboard plow a depth of plowing 30 $\mathrm{cm}+$ disc harrows a depth of $10 \mathrm{~cm}\left(\mathrm{~T}_{3}\right)$.

The experiment was split-plots in R.C.B.D design with three replicates. Tillage systems applied in main plots while corn genotypes applied in sub plots. 
The dimensions of experimental units were $2.8 \times 4 \mathrm{~m}$ with area $11.2 \mathrm{~m}^{2}$. The distance between the plants was $25 \mathrm{~cm}$, while the distance between rows was $70 \mathrm{~cm}$. Random samples were taken from the experimental soil before plowing from different depths $(0-15,15-30$ and 30-45 cm), to estimate some chemical and physical soil properties (table 1). In addition samples of irrigation water were taken to estimate the salinity ratio in irrigation water in laboratories of the College of Agriculture, University of Basrah.

Table (1): Some of physical and chemical properties of the soil field before plowing.

\begin{tabular}{|c|c|c|c|c|c|c|}
\hline Depth $(\mathrm{cm})$ & $\begin{array}{c}\mathrm{pb} \\
\left(\mathrm{Mg} \mathrm{m}^{-3}\right)\end{array}$ & $\begin{array}{c}\text { E.C. soil } \\
\left(\mathrm{dsm}^{-1}\right)\end{array}$ & $\begin{array}{l}\text { E.C. water } \\
\left(\mathrm{dsm}^{-1}\right)\end{array}$ & $\mathrm{pH}$ & \multicolumn{2}{|c|}{$\begin{array}{c}\text { Texture } \\
\left(\mathrm{gm}^{\mathrm{km}} \mathrm{kg}^{-1}\right)\end{array}$} \\
\hline $0-15$ & 1.48 & 8.19 & \multirow{3}{*}{2.5} & \multirow{3}{*}{7.65} & Sand & 100.0 \\
\hline $15-30$ & 1.50 & 8.60 & & & Silt & 465.0 \\
\hline $30-45$ & 1.50 & 8.80 & & & Clay & 435.0 \\
\hline & & & & & \multicolumn{2}{|c|}{ Silty loam } \\
\hline
\end{tabular}

The soil of the experiment was fertilized with $200 \mathrm{~kg} \mathrm{ha}^{-1}$ triple super phosphate (46\% $\mathrm{P}_{2} \mathrm{O}_{5}$ ) which added before planting, nitrogen fertilizer as form of urea $(46 \% \mathrm{~N})$ was added at rate of $300 \mathrm{~kg} \mathrm{ha}^{-1}$ at three timing, the first one at planting, while the second dose added when the plant height was $30 \mathrm{~cm}$ and the third dose has been added at the flowering stage (Mohsin, 2007).

Two doses of liquid diazinon $(60 \%$ active material) 6 litres ha $^{-1}$ was added to avoid corn stalk borer (sesame criteca), The first dose was applied 20 days after planting while the second dose applied after 15 days of first dose (Al-Jubouri \& Anwar, 2009).

The following characteristics were studied: number of days until 50\% tasseling and silking, leaf area was calculated according to (Asekabta, 2018), stem diameter was evaluated on the second internode above the ground with a digital caliper (Mendes Fagherazzi et al., 2018).
The data were analyzed statistically as analysis of variance using the statistical program SPSS (Version 23) according to the split plot design. The means were compared using the least significant differences (L.S.D) at the 0.05 probability level (table 2).

\section{Results \& Discussion}

\section{Number of Days until 50\% tasseling.}

Genotypes vary in the duration of tasseling and silking depending on the genotype, morphological characteristics and responsiveness to environmental conditions (Al-Jubouri \& Anwar, 2009).

The results explained that the genotypes significantly deferent in number of days until 50\% tasseling (table 3). Both genotypes $V_{3}$ and $V_{2}$ recorded the highest number of days until 50\% tasseling. The genotypes $\mathrm{V}_{3}$ and $\mathrm{V}_{2}$ recorded 62.222 and 61.778 days. The genotypes $\mathrm{V}_{1}$ and $\mathrm{V} 4$ had the lowest average of the number of days 
until $50 \%$ tasseling which were 60.333 and 60.556 days. This was due to genetic differences between the varieties or perhaps their environmental needs. These results in agreement with results of other researchers
Kökten \& Akçura, (2017) and Mendes Fagherazzi et al. (2018), they reported that corn genotypes had a significant effect on the number of days to tasseling.

Table (2). Mean square of genotypes and tillage systems on growth characteristic of maize.

\begin{tabular}{|l|c|c|c|c|c|}
\hline \multicolumn{1}{|c|}{ Sources of variation } & df & $\begin{array}{c}\text { Number of } \\
\text { days until 50\% } \\
\text { tasseling }\end{array}$ & $\begin{array}{c}\text {. Number of } \\
\text { days until } \\
50 \% \text { silking }\end{array}$ & Leaf area & Stem \\
diameter \\
\hline Replicates & 2 & 1.361 & 2.333 & 5810.341 & 0.108 \\
\hline Tillage Systems(T) & 2 & $103.528^{*}$ & $70.750^{*}$ & $984213.724^{*}$ & $124.651^{*}$ \\
\hline Error A & 4 & .0486 & 0.208 & 3141.876 & 0.213 \\
\hline Corn genotypes(V) & 3 & $7.630^{*}$ & $7.333^{*}$ & $273913.108^{*}$ & $14.050^{*}$ \\
\hline $\mathrm{T} \times \mathrm{V}$ & 6 & $2.311^{\mathrm{ns}}$ & $1.515^{\mathrm{ns}}$ & $99366.691^{*}$ & $14.123^{*}$ \\
\hline Error B & 18 & .0889 & 0.583 & 19217.165 & 0.301 \\
\hline Total & 35 & - & - & - & - \\
\hline
\end{tabular}

* Significant at 0.05 probability level; ns Not significant

The results of table (3) revealed that tillage systems have significant effect on the number of days until $50 \%$ of tasseling. Moreover the results revealed that $T_{2}$ gave the highest days number which reached to 63.333 days. While the tillage system $\mathrm{T}_{1}$ gave the lowest average which is 58.000 days. This is may be due to increase soil aeration and increase proliferation of roots for uptake of more nutrients by the plant in deep tillage systems, this lead to increase the duration of vegetative growth. Our results was in agreement with results of other researchers Malagi (2010) and Basir et al. (2016), which they are reported that tillage systems had a significant effect in the number of days until tasseling.

\section{Number of Days until 50\% silking.}

Corn genotypes and tillage system had significant effects on number of days until $50 \%$ silking.
The results of table (4) exhibited that the highest number of days until $50 \%$ silking (65.111 days) was found by $\mathrm{V}_{3}$ while the average day until $50 \%$ silking of $\mathrm{V}_{2}$ was 64.333 days with insignificant differences from $V_{3}$, while the genotype $V_{1}$ had the lowest average 63.111 days. This is due to the genotypes varying in the number of days required for tasseling and silking on the species and its morphological characteristics and its responsiveness to environmental conditions. Our results was in agreement with the results of Imorou et al. (2018) and Abdullah \& Karim (2019), which they are found that corn genotypes had a significant effect on the number of days to silking. The results of table (4) indicated that, the highest number of days until 50\% silking (66.083 days) was recorded by $\mathrm{T}_{2}$, while tillage system $T_{1}$ had the lowest average 61.333 days. Due to role of tillage in expanding the growth period of plant and 
Zaidan et al. / Basrah J. Agric. Sci., 32(2): 7-15

Table (3): Effect of Corn genotypes and tillage systems on number of days until $50 \%$ tasseling.

\begin{tabular}{|c|c|c|c|c|c|}
\hline \multirow{2}{*}{ Tillage systems } & \multicolumn{4}{|c|}{ Corn genotypes } & \multirow{2}{*}{$\begin{array}{c}\text { Tillage system } \\
\text { mean }\end{array}$} \\
\cline { 2 - 5 } & $\mathrm{V}_{1}$ & $\mathrm{~V}_{2}$ & $\mathrm{~V}_{3}$ & $\mathrm{~V}_{4}$ & .58000 \\
\hline $\mathrm{T}_{1}$ & .59333 & 57.667 & 58.000 & 57.000 & .63750 \\
\hline $\mathrm{T}_{2}$ & 61.333 & 64.667 & 65.667 & 63.333 & 61.917 \\
\hline $\mathrm{T}_{3}$ & 61.000 & 63.000 & 63.000 & 60.667 & \\
\hline Genotypes mean & 60.556 & 61.778 & 62.222 & 60.333 & Interaction \\
0.05 & \multicolumn{3}{c}{$\begin{array}{c}\text { Genotypes } \\
.07707\end{array}$} & $\begin{array}{c}\text { Tillage systems } \\
0.6067\end{array}$ & N.S \\
\hline
\end{tabular}

Table (4) effect of Corn genotypes and tillage systems on number of day until 50\% silking.

\begin{tabular}{|c|c|c|c|c|c|}
\hline \multirow{2}{*}{ Tillage systems } & \multicolumn{4}{|c|}{ Corn genotypes } & \multirow{2}{*}{$\begin{array}{c}\text { Tillage system } \\
\text { mean }\end{array}$} \\
\cline { 2 - 5 } & $\mathrm{V}_{1}$ & $\mathrm{~V}_{2}$ & $\mathrm{~V}_{3}$ & $\mathrm{~V}_{4}$ & 61.333 \\
\hline $\mathrm{T}_{1}$ & 62.667 & 61.000 & 61.000 & 60.667 & 66.083 \\
\hline $\mathrm{T}_{2}$ & 62.667 & 67.000 & 68.667 & 66.000 & 64.583 \\
\hline $\mathrm{T}_{3}$ & 64.000 & 65.000 & 65.665 & 63.667 & \\
\hline Genotypes mean & 63.111 & 64.333 & 65.111 & 63.444 & Interaction \\
L.S.D at the & \multicolumn{3}{c|}{ Genotypes } & Tillage systems & N.S \\
\hline
\end{tabular}

delayed number of days to tasseling, this reflected on the number of days silking

\section{Leaf area.}

The leaf area of the plant was affected significantly by corn genotypes. The results of table 5 shows that the highest leaf area obtained from the $\mathrm{V}_{3}$ which reached to $4398.841 \mathrm{~cm}^{2}$ while the leaf area of $V_{2}$ was $4341.340 \mathrm{~cm}^{2}$ and did not differ significantly from $V_{3}$ compared to the $V_{4}$, which had a leaf area of $40098 \mathrm{~cm}^{2}$. These differences may be attributed to genetic factors and their interaction with the prevailing environmental conditions, which led to their differences in the leaf area. Our results is in agreement with result of Dadashi et al. (2014) and Rubaie \& AlUbaidi (2018), which they are reported that corn genotypes had a significant effect on the leaf area.

The treatment $T_{2}$ was superior by give the highest leaf area which reached to $4512.900 \mathrm{~cm}^{2}$ compared with $\mathrm{T}_{3}$ and $\mathrm{T}_{1}$ treatments which they gave a leaf area reached to 4252.838 and $3940.908 \mathrm{~cm}^{2}$ respectively (Table 5). Due to the role of tillage in improving favorable condition for plant growth and nutrients were readily available and increased the duration of vegetative growth which led to the increase in leaf area. Our results are in agreement with Malagi (2010) and Ijoyah et al. (2013), which they are reported that different tillage systems had a significant effect in the leaf area. 
The interaction between the corn genotypes and tillage systems were also significant in this character (Table 5). The highest value of leaf area obtained the tillage system $\left(\mathrm{T}_{2}\right)$ and genotype $\mathrm{V}_{3}$ which reached
$4847.893 \mathrm{~cm}^{2}$ with insignificant differences from $\mathrm{T}_{2} \times \mathrm{V}_{2}$. While, the interaction $\mathrm{T}_{1} \times \mathrm{V}_{4}$ had the lowest leaf area reached 3694.677 $\mathrm{cm}^{2}$

Table (5): Effect of the corn genotypes and tillage systems on leaf area $\left(\mathrm{cm}^{2}\right)$.

\begin{tabular}{|c|c|c|c|c|c|}
\hline \multirow{2}{*}{ Tillage systems } & \multicolumn{4}{|c|}{ Corn genotypes } & \multirow{2}{*}{$\begin{array}{c}\text { Tillage } \\
\text { system mean }\end{array}$} \\
\hline & $\mathrm{V}_{1}$ & $\mathrm{~V}_{2}$ & $\mathrm{~V}_{3}$ & $\mathrm{~V}_{4}$ & \\
\hline $\mathrm{T}_{1}$ & 4070.030 & 3971.417 & 4027.510 & 3694. & 3940.908 \\
\hline $\mathrm{T}_{2}$ & 4292.727 & 4779.897 & 4847.893 & 4131. & 4512.900 \\
\hline $\mathrm{T}_{3}$ & 4218.840 & 4272.707 & 4321.120 & 4198. & 4252.838 \\
\hline Genotypes mean & 4193.866 & 4341.340 & 4398.841 & 4008. & \\
\hline \multicolumn{2}{|c|}{$\begin{array}{c}\text { L.S.D at the } \\
0.05\end{array}$} & $\begin{array}{c}\text { Genotypes } \\
113.3150 \\
\end{array}$ & \multicolumn{2}{|c|}{$\begin{array}{c}\text { Tillage systems } \\
48.7872 \\
\end{array}$} & $\begin{array}{c}\text { Interaction } \\
196.2674\end{array}$ \\
\hline
\end{tabular}

plant stem diameter $(25.194 \mathrm{~mm})$ was

\section{Stem diameter}

Table (6) showed that various genotypes significantly affected stem diameter. $\mathrm{V}_{4}$ cultivar was superior by giving the highest mean of stem diameter (24.173mm) compared with $\mathrm{V}_{3}$, which gave the lowest $(21.118 \mathrm{~mm})$. Our results was in agreement with Shi et al. (2016) and Mohamed et al. (2018), they reported that corn genotypes had a significant effect on the stem diameter.

Table (6) displayed that tillage systems significantly affected stem diameter. High obtained at $\mathrm{T}_{3}$ tillage system, whereas the lowest plant stem diameter (19.042) was

observed in $T_{1}$. The cause of the superiority of the tillage systems $T_{3}$ is that the mechanism of work of Moldboard plow in dismantling soil and heart of plant remains, created a good conditions for decomposition of organic matter, which is positively reflected in the provision of nutrients, which helped to increase the growth of secondary and main roots.

Table (6): Effect of corn genotypes and tillage system in stem diameter (mm).

\begin{tabular}{|c|c|c|c|c|c|}
\hline \multirow{2}{*}{ Tillage systems } & \multicolumn{4}{|c|}{ Corn genotypes } & \multirow{2}{*}{$\begin{array}{c}\text { Tillage } \\
\text { system mean }\end{array}$} \\
\hline & $\mathrm{V}_{1}$ & $\mathrm{~V}_{2}$ & $\mathrm{~V}_{3}$ & $\mathrm{~V}_{4}$ & \\
\hline $\mathrm{T}_{1}$ & 16.053 & 19.303 & 18.850 & 21.963 & 19.042 \\
\hline $\mathrm{T}_{2}$ & 25.850 & 23.923 & 21.797 & 23.573 & 23.786 \\
\hline $\mathrm{T}_{3}$ & 25.973 & 25.113 & 22.707 & 26.983 & 25.194 \\
\hline Genotypes mean & 22.626 & 22.780 & 21.118 & 24.173 & \\
\hline \multicolumn{2}{|c|}{$\begin{array}{l}\text { L.S.D at the } \\
0.05\end{array}$} & $\begin{array}{r}\text { Genotyp } \\
0.448\end{array}$ & \multicolumn{2}{|c|}{$\begin{array}{c}\text { Tillage systems } \\
0.4017\end{array}$} & $\begin{array}{c}\text { Interaction } \\
0.7767\end{array}$ \\
\hline
\end{tabular}




\section{Zaidan et al. / Basrah J. Agric. Sci., 32(2): 7-15}

Our results was in agreement with Shahzad et al. (2015) and Anjum et al. (2019), they reported that tillage systems had a significant effect in the stem diameter.

The interaction between corn genotypes and tillage system were also significant in stem diameter (Table 6). The highest value of stem diameter obtained in the tillage system $\left(\mathrm{T}_{3}\right)$ and genotype $\left(\mathrm{V}_{4}\right)$ which reached 26.983 mm while; the interaction $\left(\mathrm{T}_{1} \times \mathrm{V}_{1}\right)$ gave the lowest stem diameter $(16.053 \mathrm{~mm})$. This may be due to the combined effect of the tillage system and it is role in creating favourable conditions for the analysis of organic matter, which was reflected in the provision of nutrients, which helped to increase the growth of secondary roots and extension of the roots as well as the variation between the genotypes in the character of stem diameter, which was reflected in increased of stem diameter.

\section{Conclusions.}

The results of this study showed that genotypes Baghdad-3 and Al-Maha gave the highest value for most characters; Number of days until 50\% tasseling (62.222 and 61.778 days), Leaf area (4341.340 and $4398.841 \mathrm{~cm}^{2}$ ) respectively. While the genotype Sara was superior in Stem diameter which was $24.173 \mathrm{~mm}$.Corn genotypes generally enhanced using $\mathrm{T}_{2}$ and $\mathrm{T}_{3}$ systems compared with $T_{1}$. The $T_{2}$ and $T_{3}$ tillage system led to a significant increase in most of the characteristics of growth, The $\mathrm{T}_{2}$ tillage system significantly increased the Number of days until $50 \%$ tasseling by $7.23 \%$, leaf area by $14.51 \%$. While the $\mathrm{T}_{3}$ tillage system increased stem diameter by $14.50 \%$ compared to the $T_{1}$ Tillage system.

\section{Acknowledgements}

The author thanks the Department of Field Crops, college of Agriculture, University of
Basrah, in particular, Dr. Kadhim H. Huthily and Dr. Sundus A. Mohammed for providing support and assistance in the statistical analysis of data and assistance in the preparation of research.

Conflict of interest: The authors declare that they have no conflict of interest.

Dr. Sadiq Muhsin: Orcid: https://orcid.org/0000-0001-9512-9947.

\section{Dr. Kareem H. Mohsin:}

\section{Reference}

Abdullah, A.H. \& Karim, A.A.K. (2019). Evaluation of F1S', F2S 'hybrids, heterosis, and inbreeding depression of Maize (Zea mays L.). Tikrit J. Agric. Sci., 19(1): 1-17.

Al-Jubouri, S.M.I. \& Anwar, A.M. (2009). Influence of different levels and application dates of nitrogen fertilizer on growth of two Corn varieties (Zea mays L.) Jord. J. Agric. Sci., 5(1): 57-72.

Al-Obaidy, D.S.M.; Al-Juboory, J.M.; AlJuboory, A.H. (2015). Estimating of genetic parameters and construction of selection indices for exotic and endogenous maize genotypes. Tikrit J. Agric. Sci., 15(1): 8-17.

Alrijabo, A.S. (2012). Effect of a new farming system (zero-tillage) on the growth, yield and its components of bread wheat, durum wheat and barley crops in the moderate rainfall area of Ninevah province. Mesop. J. Agric., 42(1): 1-16.

Al-Rubaie, M. A. \& Al-Ubaidi M. O. G. (2018). Response of maize yield and yield components to tillage system and plant population. Iraqi J. Agric. Sci., 49(6): 944958.

Anjum, S.A.; Raza, M.M.; Ullah, S.; Yousaf, M. M.; Mujtaba, A.; Hussain, M.; Shah, M.J.; Ahmad, B. 


\section{Zaidan et al. / Basrah J. Agric. Sci., 32(2): 7-15}

\& Ahmad, I. (2019). Influence of different tillage practices on yield of autumn planted maize (Zea mays 1.). pak. j. agric. res., 32(2), 293-301.

Asekabta, K.A.N. (2018). Effects of tillage, cropping system and NPK fertilizer rate on performance of maize (Zea mays L.)/soybean (Glycine max L.(Merill)) intercropin the guing savannah a goecological zone of ghahna Ph.D. Thesis, Univ. Dev. Stud. Philos. Deg. Crop: 165pp.

Basir, A.; Jan, M.A. \& Khan, J.M. (2016). Response of tillage, nitrogen and stubble management on phenology and crop establishment of wheat, Int. J. Agric. Biol., 18(1): 18.

Dadashi, F.; Zaefarian, F.; Abbassi, R.; Bahmanyar, M.A. \& Rezvani, M. (2014). Response of leaf area and dry matter for crop, weeds and cover crops to competition and fertilizer resources. Acta Agr. Slov.,103(1): 27-36.

Haddadi, M.H. (2016). The effects of tillage system and varieties on yield and yield components of corn (Zea mays L.). Int. J. Farming All. Sci., 5(1): 16-20.

Ijoyah, M.; Fedoje, Y. \& Usman, A. U. (2013). Effects of varied tillage methods on yields of maize-okra intercropping system in Makurdi, Nigeria. Glob. J. Bio. Sci., 2(6): 247 254.

Mohsin, K.H. (2007). Response of Yellow corn to different levels of nitrogen, iron and zinc elements and their interventions under the southern region of Iraq, Ph. D. Thesis, Coll.
Agric., Univ. Basra: 175pp. (In Arabic):

Muhsin, S.J. (2017). Performance study of moldboard plow with two types of disc harrows and their effect on some soil properties under different operating conditions. Basrah J. Agric. Sci., 30(2): 1-15.

Imorou, L.; Ahoton, E. L.; Wallis, N. Z. \& Kanlindogbe, C. (2018). Water stress effect on agro-morphological and physiological parameters of three local cultivars of maize (Zea mays L.) of South Benin. Int. J. Biol. Chem. Sci., 12(5): 2294-2308.

Khether, A.A. (2017). Response of two corn (Zea mays L.) genotypes to herbicides application. Kirkuk Univ. J. Agric. Sci., 8(5): 188-203.

Khorami, S.; Kazemeini, S.; Afzalinia, S. \& Gathala, M. (2018). Changes in soil properties and productivity under different tillage practices and wheat genotypes: A short-term study in Iran. Acta. Agr. Sust, 10(9): 1-17.

Kökten, K. \& Akçura, M. (2017). Performances of hybrid dent maize cultivars in bingöl conditions. Süle Univ J. Nat. Lan., 21(1): 261-265.

Malagi, M. T. (2010). Effect of spentwash and tillage on growth, yield and juice quality of sweet sorghum (Sorghum bicolor L.). Ph. D. Thesis, Univ. Panjab, India: $135 \mathrm{pp}$.

Mendes Fagherazzi, M.; Souza, C.A.; Stefen, D.L.V.; Zanesco, P.R.; Junkes, G.V.; Coelho, C.M. \& Sangoi, L. (2018). Phenological sensitivity of two maize cultivars to trinexapac-ethyl. SBCPD J., 36(1): 110. 


\section{Zaidan et al. / Basrah J. Agric. Sci., 32(2): 7-15}

Mohamed, A.; Mohamed, I. \& Daffalla, A. (2018). Effect of nitrogen fertilization and cultivar on growth and grain yield of maize (Zea mays L.). Gezira J. Agric. Sci., 16(1): 52-63.

Osunbitan, J.A.; Oyedele, D.J.\& Adekalu, K.O. (2005). Tillage effects on bulk density hydraulic conductivity and strength of a loam sand soil in southwestern Nigeria. Soil Till. Res., 82(1): 57-64.

Ozturk, H.H.; Ekinci, K. \& Barut, Z.B. (2006). Energy analysis of the tillage systems in second crop corn production. Sust J. Agric, 28(3), 25-37.

Shahzead, K; Khan, A.; Smith, J.; Saeed, M. \& Khan, S.A. (2015).
Response of maize to different nitrogen sources and tillage systems under humid subtropical conditions. J Anim Plant SCI., 25(1): 189-197.

Shi, D.Y.; Li, Y.H., Zhang; J.W., Liu; P.; Zhao, B. \& Dong, S.T. (2016). Effects of plant density and nitrogen rate on lodging-related stalk traits of summer maize. Soil Environ. J., 62(7): 299-306.

USDA. (2019). World agriculture production, foreign agriculture service, office of global analysis, Washington. Circular Series WAP: 18pp. 